\title{
The Impact of Ethical Sales Behavior on Customer Loyalty: A Case from Vietnam
}

\author{
Nguyen Minh Tuan ${ }^{1}$ \\ ${ }^{1}$ School of Business, International University-Vietnam National University of Ho Chi Minh city, Vietnam \\ Correspondence: Nguyen Minh Tuan, School of Business, Vietnam National University, Block 6, Linh Trung \\ Ward, Thu Duc District, Ho Chi Minh city, Vietnam. Tel: 84-913-920-620. E-mail: nmtuan@hcmiu.edu.vn
}

Received: January 24, 2014

doi:10.5539/ijbm.v10n3p152
Accepted: February 2, $2015 \quad$ Online Published: February 27, 2015

URL: http://dx.doi.org/10.5539/ijbm.v10n3p152

\begin{abstract}
This paper attempts to investigate the effect of ethical sales behavior on customer loyalty in the context of sales representatives of Procter \& Gamble (P\&G) at Metro Cash \& Carry (MCC) supermarkets toward customers. The result of this study is expected to be applicable in fast-moving-consumer-good (FMCG) industry. The applied model in this paper includes four concepts of ethical sales behavior, customer trust, customer commitment, and customer loyalty. Questionnaires were used to collect data through phone survey. Cronbach alpha, Exploratory Factor Analysis, Confirmatory Factory Analysis, and Structural Equation Modeling were used to analyze data collected from 203 customers who are retailers or traders buying P\&G products at MCC system. In addition, multiple group analyses regarding gender and purchasing power were also performed. Furthermore, qualitative interviews were also conducted with five (5) customers purchasing P\&G products to understand customer response with unethical sales behavior. The results show that there is only indirect impact of ethical sales behavior on customer loyalty through customer trust and customer commitment as mediating variables. Customer commitment has direct effect on customer loyalty, but customer trust only influences customer loyalty through customer commitment. No difference in gender or purchasing power is found regarding the impact of ethical sales behavior on customer loyalty.
\end{abstract}

Keywords: ethical sales behavior, customer trust, customer commitment, customer loyalty, Vietnam

\section{Introduction}

Nowadays, smart managers have been looking beyond customer satisfaction toward customer loyalty because customer satisfaction is not the sign of repurchasing. In marketing management, it is crucial to ensure customer loyalty and obtain benefits from extending customer life as profitable and long-term investments for any business. In general, customer loyalty has been recognized as an important source of sustainable competitive advantages due to customer retention, repurchase, and long-term customer relationships (Ganesh, Arnold, \& Reynolds, 2000; Rust, Zeithaml, \& Lemon, 2000).

In service organizations, salespersons are most visible representatives (Crosby, Evans, \& Cowles, 1990) and their face to face interactions with customers have been traditionally considered as one of the most important determinants of customer loyalty (Grönroos, 1990). However, such a relationship may be spoiled by salespersons' dishonest and untrustworthy behaviors (Kelly \& Schine, 1992). Those immoral actions not only influence customers' perspectives, but also hurt the customer commitment, trust, and loyalty. Many previous studies mentioned the ethical sales behavior under supervisor's perceptions (e.g. Ramsey, Marshall, Johnston, \& Deeter-Schmelz, 2007). Nevertheless, this current study focuses on the concept of ethical sales behaviors from the customers' perspectives.

A salesperson who behaves ethically is more effective at building customer relationships, as well as getting customers satisfied, trusted, and committed (Hansen \& Riggle, 2009). Consumers often rely on salespersons who are representatives of business to provide the correct information and proper guidance (Howe, Hoffman, \& Hardigree, 1994). Therefore, good ethics in business can enhance business results, which leads to sustainable development of organizations (Weeks, Loe, Chonko, \& Wakefield, 2006).

Notwithstanding the influences of ethical sales behaviors on customer loyalty are generally recognized, there have been limited empirical demonstrations in reality (Hansen \& Riggle, 2009). The idea of this current research 
came during the internship of one International University student in one Metro Cash \& Carry (MCC) supermarket who recognized the unethical practice of sales representatives of Procter \& Gamble (P\&G) in the MCC system as follows:

- Does not inform customers about promotional campaigns;

- Retains gift vouchers;

- Retains promotional products;

- Does not keep promise about delivery of missing items.

When customers discovered the truth, they often made a lot of complaints to $P \& G$, lost loyalty to $P \& G$, and at worst they switched to other competitors. This has caused head-ache for P\&G. Consequently, with the support from $P \& G$ management, we conducted this current research on relationships among ethical sales behavior, relationship quality, and customer loyalty regarding the practice of business conduct of $P \& G$ in Vietnam.

\section{Literature Review}

\subsection{Ethical Sales Behavior}

Nowadays, ethical sales behavior plays an vital role in promoting customer welfare for organizations (Roman \& Ruiz, 2005). An organization is perceived as ethical when its customers expect its ethical sales behaviors (Ganesh et al., 2000). Ethical behaviors of salespersons are defined as conformance to social norms including fair play, honesty, and full disclosure (Roberson \& Anderson, 1993), which enable salespersons to foster customer long-term relationship based on customer satisfaction and trust (Roman \& Munuera, 2005). However, it is often very difficult to draw the line between ethical behaviors and unethical ones because we must base on proposed acts which are about right versus wrong, good versus evil, fair versus unfair, or just versus unjust (Roman, 2003). Moreover, a salesperson is only perceived ethical in a specific situation with ambiguous constructs (Lagace, Dahlstrom, \& Gassenheimer, 1991). In other words, ethical sales behavior is regarded as a mutual relationship in fair and equitable exchange; and when customers perceive a favorable relationship, a positive feedback will probably be initiated.

Previous studies (Hansen \& Riggle, 2009; Lagace et al., 1991; Roman \& Ruiz, 2005) pointed out that a short-run salesperson's behavior which can enable him/her to gain at the expense of customers is considered unethical sales behavior. To be more specific, those activities include giving deceiving benefits of a product/service; lying or exaggerating product availability, or the competitor's information; selling obsolete products/services; responding to customers with unreliable answers; and implementing pressing selling techniques (Cooper \& Frank, 2002; Futrell, 2002), which can give rise to customer frustration, bad images, loss of sales and profits (Burnett, Pettijohn, \& Keith, 2008). This current study use the definition of Roman (2003) which focuses on the salesperson ethical behavior perceived by customers during interaction.

\subsection{Trust}

Trust is defined as the belief, feeling or expectation from partner's expertise, reliability and intentions (Cater \& Zabkar, 2008) in all relational exchanges. Speckman (1988) also depicted that trust is a key component to maintain "the cornerstone of the strategic partnership" in company's development. In other words, customer trust to salespersons is a central component of the ongoing relationships, where salespersons provide generously and honorably benefits to customers (Morgan \& Hunt, 1994). In addition, trust is not merely based on a single exchange episode. It is established through repetitive interactions between both parties in which the buyers perceives the sellers to be reliable, competent, truthful, unbiased, liable, and benevolent (Roman \& Ruiz, 2005). Moreover, customer trust also has a positive connection with a low-pressure selling (Kennedy, Ferrell, \& Leclair, 2001), and honest actions (Beatty et al., 1996) which are parts of ethical sales behaviors. In general, trust is seen as a significant determinant of success in the service encounter (Coulter \& Coulter, 2003). In that sense, the operational definition of customer trust to salespersons in this current research was based on that of Morgan and Hunt (1994).

\subsection{Commitment}

Commitment is one of the most vital dimensions in relationship marketing paradigm (Adamson, Chan, \& Handford, 2003). Moorman, Zaltman, and Deshpande (1992) defined commitment as the desire or intention to sustain a valuable relationship. Gilliland and Bello (2002) indicated that commitment is an important attitudinal construct. Anderson and Narus (1990) pointed out that the commitment to sustain long-lasting interactions is a determinant of all successful working relationships. In reality, relationship commitment can be viewed as an implicit or explicit pledge about the stability of a relationship between exchange parties. It is the utmost phase of 
interdependence between sellers and purchasers in various relationship marketing models including those describing buyer-seller relationships and channel behavior. It is a good evidence of long-term relationships (Morgan \& Hunt, 1994) and can act as the ultimate in relational bonding (Dwyer, Schurr, \& Oh, 1987). Customer perceived fairness has strong impact on customer loyalty toward the company (Poujol, Siadou-Martin, Vidal, \& Pellat, 2012). If customers feel that they are treated unfairly by salespersons, they are likely to end the relationship (Morgan \& Hunt, 1994). The operational definition of customer commitment in this current study was based on Moorman et al. (1992).

\subsection{Customer Loyalty}

In practice, loyalty is seen as one of the most important criteria for a company to obtain competitive advantage because it determines customers' repurchase in future (Oliver, 1999) in spite of various marketing efforts of competitors and situational influences on them (Lin, 2012). Cristobal (2007) pointed out that perceived quality stimulates satisfaction, and that satisfaction increases customer loyalty. Thanks to rapid development of service industries during last decades, the concept of customer loyalty has expanded to cover not only tangible products but intangible ones, and not only actual purchasing behavior but combined measures of behavior and attitude (Lin, 2012). Nowadays, many companies implement customer respect oriented strategies to attract, retain, and get on well with customers (Chang \& Chen, 2007). An expectation of continuity indicates the customer's intention to manage the relationship and the likelihood of repurchase (Palmatier, Dant, Grewal, \& Evans, 2006). The operational definition of customer loyalty was based on Lin (2012).

\subsection{Relationship Quality}

Relationship quality has been a useful tool to produce long-term customer relationship in various industries. Relationship quality can represent the psychological connection between customers and retailers or service providers (De Wulf, Oderkerken-Schroder, \& Iacobucci, 2001; Crosby et al., 1990). In addition, such relationship quality can be used as an instrument to assess the well-being of these relationships (De Wulf et al., 2001). Many studies have recognized benefits of relationship marketing which can lead to better competitive advantages (e.g. Veloutsou, Saren, \& Tzokas, 2002). De Wulf et al. (2001) proposed that the construct of relationship quality which is reflected by a combination of commitment, trust, and relationship offers the best assessment of relationship strength and provides the most insight into exchange performance. Gregoire (2006) identified relationship quality as a mix of trust, relationship satisfaction, commitment, and identification. The structure and underlying dimensions of relationship quality may vary across empirical studies due to different purposes. However, there is the belief that no single dimension or relational construct can fully define the overall depth or climate of an exchange relationship (Alrubaiee \& Al-Nazer, 2010; De Wulf et al., 2001). Thanks to all above-mentioned researches, this current study developed relationship quality using trust and commitment as two main components to evaluate customers' long-term relationships.

\subsection{Hypotheses about Relationships among Ethical Sales Behavior, Customer Trust, Customer Commitment, and Customer Loyalty}

\subsubsection{Ethical Sales Behavior and Trust}

Various studies have shown that customer trust in a salesperson can be earned through his/her honest actions (Alrubaiee, 2012; Swan, Bowers, \& Richardson, 1999). Swan et al. (1998) concluded that salespersons' behaviors can help to establish trust between themselves and their customers. Chen and Mau (2007) also showed that ethical or unethical behaviors of salespersons can develop or ruin customer trust. Furthermore, there were empirical evidences in B2C to support the idea that a salesperson's ethical behavior positively affects customer trust (Roman \& Ruiz, 2005), and similar results were also observed in B2B fields (Hansen \& Riggle, 2009).

\section{H1: Ethical sales behavior has positive effect on customer trust}

\subsubsection{Ethical Sales Behavior and Commitment}

Hansen and Riggle (2009) pointed out that the influence of ethical sales behavior on customer commitment is totally mediated by customer trust to the salesperson. Nonetheless, because we wanted to fully investigate the impact of ethical sales behavior on other constructs in a different context, the following hypothesis was set up for testing.

\section{H2: Ethical sales behavior has positive effect on customer commitment}

\subsubsection{Trust and Commitment}

Trust and commitment have often been jointly examined in relationship marketing studies. Many researches regarded trust as an antecedent of both commitment and successful relationships (Cater \& Zabkar, 2008; Stanko, 
Bonner, \& Calantone, 2007). Anyhow, several studies considered trust as one of the prominent behavioral determinants of commitment (Karande, Jungbok, \& Anusorn, 2008; Hess \& Story, 2005; Morgan \& Hunt, 1994). When trust is high, customers will enjoy working with the salespersons, and be more likely to carry on the relationships (Cater \& Zabkar, 2008). On the other hand, customers cannot sustain relationship with suppliers who do not seem to be benevolent, honest or competent (Morgan \& Hunt, 1994).

\section{H3: Customer trust has positive effect on customer commitment}

\subsubsection{Trust and Loyalty}

Loyalty can be defined as a complement of trust (Josep \& Velilla, 2003). The degree of customer loyalty is an important consideration for service-oriented firms (Agnihotri, Kothandaraman, \& Kashyap, 2012). Customer loyalty to a service company can be conceptualized as a set of customers' intention to maintain an ongoing relationship with the service company and to recommend it to other consumers (Sirdeshmukh, Singh, \& Sabol, 2002; Singh \& Sirdeshmukh, 2000; Bloemer \& De Ruyter, 1999). Roman (2003) found that ethical sales behavior has a positive impact on customer satisfaction, trust, and loyalty to the company. Based on the above-mentioned studies, we suggest the following hypothesis.

\section{H4: Customer trust has positive effect on customer loyalty}

\subsubsection{Commitment and Loyalty}

Not only the trust but also commitment directly affect loyalty (Vuuren, Roberts-Lombard, \& Tonder, 2012; Fullerton, 2003). Customer commitment highly correlates with loyalty (Dimitriades, 2006). However, commitment is more than a favorable attitude toward company reputation. It is a determinant of long-term loyalty (Morgan \& Hunt, 1994) and can be translated into customer resistance toward the competitors' actions (Bettencourt, 1997).

\section{H5: Customer commitment has positive effect on customer loyalty}

\subsubsection{Ethical Sales Behavior and Customer Loyalty}

Another hypothesis which would be tested in this current study is the direct impact of ethical sales behavior on customer loyalty. Alrubaiee (2012) proved that ethical sales behavior has indirect effect on customer loyalty through relationship quality, but the direct effect does not exist in banking sector. After all, this current study thoroughly examined the total effect of ethical sales behavior on customer loyalty regarding the different context of a different industry in a different country.

\section{H6: Ethical sales behavior has positive effect on customer loyalty}

Based on the above reasoning, we adopted the model proposed by Alrubaiee (2012) to study the relationships between Ethical Sales Behavior, Relationship Quality, and Customer Loyalty as in Figure 1.

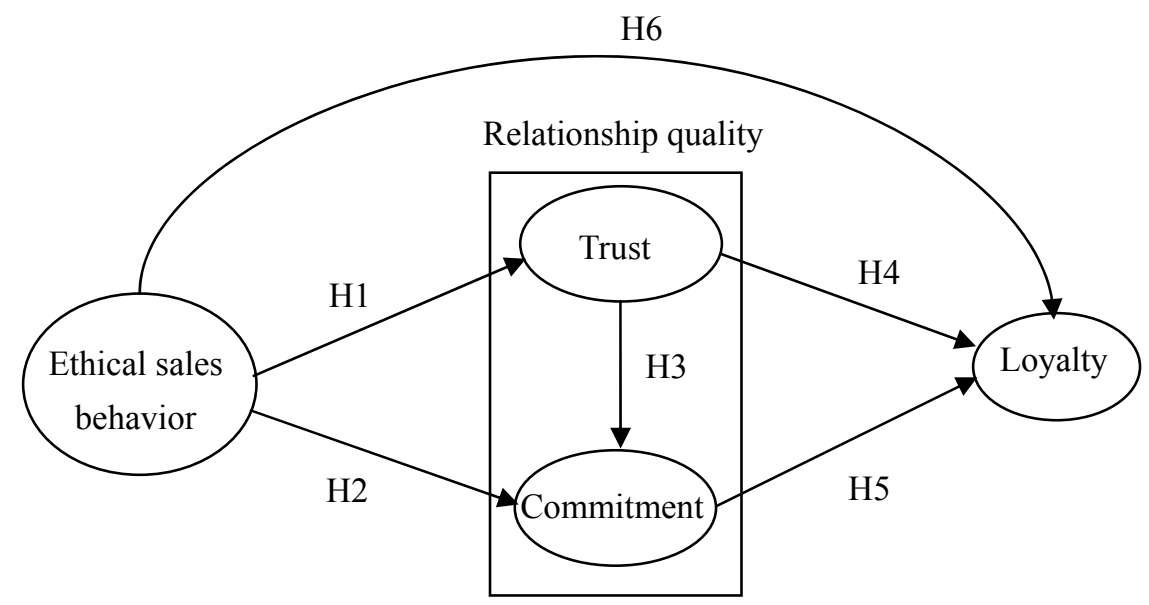

Figure 1. The proposed model

\section{Research Methodology}

Eligible respondents in this current study were retailers who buy $P \& G$ products in the MCC system nationwide 
and resell to end-users. The MCC system is the best place for data collection because of following reasons.

First of all, MCC is known as the heaven for most of household businesses, retailers or traders where they can buy a large amount of $P \& G$ products at the lowest price in the market. Therefore, customer loyalty at MCCs toward P\&G goods is often considered highest by comparison with other supermarket systems such as Coop-mart or Big C.

Second, the MCC system achieves the highest revenue from $\mathrm{P} \& \mathrm{G}$ products as a single supplier. Hence, the number of promotional products including gift vouchers and discount also reach the top rate, which is a good opportunity for profiteers. Taking advantage of lax management of $\mathrm{P} \& \mathrm{G}$, many brand representatives working at Metro have made excessive profits by violating a code of ethics dealing customers.

The questionnaire of this current research was based on operational definitions in the literature review session. Then, one P\&G supervisor and one MCC cardholder were asked to proof-read and to give any comment or modification. Next, the revised questionnaire was distributed randomly to four customers of MCC who buy P\&G products regularly and one manager in $\mathrm{P} \& \mathrm{G}$. Any item which would make respondents confused was modified before the final Vietnamese version was released as in Appendix A.

The survey was implemented to achieve a sample target of 200 customers who had purchased P\&G products regularly at 19 MCCs, namely Hiep Phu, Thang Long, Hoang Mai, Binh Phu, An Phu, Hong Bang, Ha Long, Bien Hoa, Binh Duong, Da Nang, Vinh, Long Xuyen, Hung Loi, Vung Tau, Rach Gia, Nha Trang, Buon Ma Thuot, and Qui Nhon, through telephone. The list of independent retailers was provided by supervisors at MCCs. These retailers were divided into four regions as four strata, and then stratified sampling was applied. The number of respondents for each region is proportionate to the existing number of MCCs. To be more specific, our predetermined target is:

- The Northern region with five MCCs should have 66 respondents.

- The Southern with six MCCs should have 71 .

- The Central with five smaller MCCs should have 44, and

- The Western with three supermarkets has 19.

In addition to the questionnaire survey, we conducted face-to-face interviews with five retailers at MCC An Phu in Ho Chi Minh city. The interviews were carried out at retailers' stores and recorded. The interviews were structured with questions in Appendix B. The purpose of the interviews was to get more insight about customers' reaction when they recognized unethical sales behaviors.

Reliability test, exploratory factor analysis (EFA), confirmatory factor analysis (CFA) and structural equation modelling (SEM) were performed to test the measurement model and hypotheses. Finally, multi-group analyses were also carried out regarding gender and purchasing power.

\section{Results and Findings}

215 customers were approached through telephone during the period from March $18^{\text {th }}$ to April $6^{\text {th }}, 2014$, which led to 203 respondents. The refusal rate is 5.6 percent $(=12 / 215)$ due to the interviewees were not cardholders or business owners. It took each customer about seven minutes on average to complete without any monetary incentive. However, the customers were very enthusiastic to go through the questionnaire because they really wanted to receive better quality of service. Statistics of respondents are showed in Table 1 
Table 1. Descriptive statistics

\begin{tabular}{llll}
\hline & Details & Frequency & Percentage \\
\hline Gender & Male & 104 & 51.2 \\
& Female & 99 & 48.8 \\
Region & Northern & 66 & 32.5 \\
& Central & 43 & 21.2 \\
& Southern & 74 & 36.5 \\
& Western & 20 & 9.9 \\
Average monthly bill & Below 100 million VND & 5 & 2.5 \\
& $100-200$ & 106 & 52.2 \\
How to receive promotional & Email & 74 & 36.5 \\
information & Abo-300 & 18 & 8.9 \\
& Salesperson & 37 & 18.2 \\
& Leaflets & 113 & 55.7 \\
& Advertisement & 48 & 23.6 \\
\hline
\end{tabular}

\subsection{Reliability Analysis}

In our reliability test, Cronbach alpha coefficients of these measurement scales must be greater than .6, and the item-to-total correlation must be greater than .5. The result shows that ESB1, CT1, CT4, CC5, and CL3 should be removed from the measurement scales.

\subsection{Exploratory Factor Analysis}

$\mathrm{KMO}$ is .788 which is greater than .6, and p-value in Bartlett's Test of Sphericity is .000 which is less than .05 . This result indicates that we can continue with an exploratory factor analysis (EFA).

Table 2 shows that 14 items load into four (4) constructs, which represent $56.25 \%$ of Total Variance Explained.

Table 2. Pattern matrix

\begin{tabular}{|c|c|c|c|c|}
\hline & Factor & & & \\
\hline & 1 & 2 & 3 & 4 \\
\hline CT6 & .785 & & & \\
\hline CT3 & .750 & & & \\
\hline CT2 & .743 & & & \\
\hline CT5 & .720 & & & \\
\hline $\mathrm{CC} 3$ & & .751 & & \\
\hline $\mathrm{CC} 1$ & & .747 & & \\
\hline $\mathrm{CC} 4$ & & .672 & & \\
\hline $\mathrm{CC} 2$ & & .664 & & \\
\hline CL1 & & & .801 & \\
\hline CL4 & & & .775 & \\
\hline CL2 & & & .758 & \\
\hline ESB3 & & & & .784 \\
\hline ESB2 & & & & .738 \\
\hline ESB4 & & & & .678 \\
\hline
\end{tabular}

Note. Extraction Method: Principal Axis Factoring.

Rotation Method: Promax with Kaiser Normalization.

a. Rotation converged in 5 iterations.

\subsection{Confirmatory Factor Analysis}

Assessment of Reliability and Validity of Constructs

Together with Cronbach alpha, this current study uses Composite Reliability (CR) to reassess the internal consistency with the requirement of more than .7. This requirement is met as the CRs of four concepts ESB, CT, 
CC, and CL lie within .779 and .831 .

The convergent validity is ensured with

- The standardized factor loadings of four constructs CT, CC, CL, and ESB are from .620 to .818, which are greater than .5, and

- The Average Variances Extracted (AVEs) are from .507 to .597, which are greater than .5.

Besides that, the correlations between ESB, CT, CC, and CL are from .027 to .426, which are smaller than one. This ensures the discriminant validity between concepts.

The CFA model is examined with four concepts: Ethical Sales Behavior, Customer Trust, Customer Commitment and Customer Loyalty. Five fit indices which are 2/df, GFI, TLI, CFI, and RMSEA are used to evaluate the fitness of the measurement model. Figure 2 shows that:

- $2 / \mathrm{df}<3$

- GFI, TLI, and CFI $>.90$

- RMSEA $<.05$

It indicates a good model fit for the measurement model.

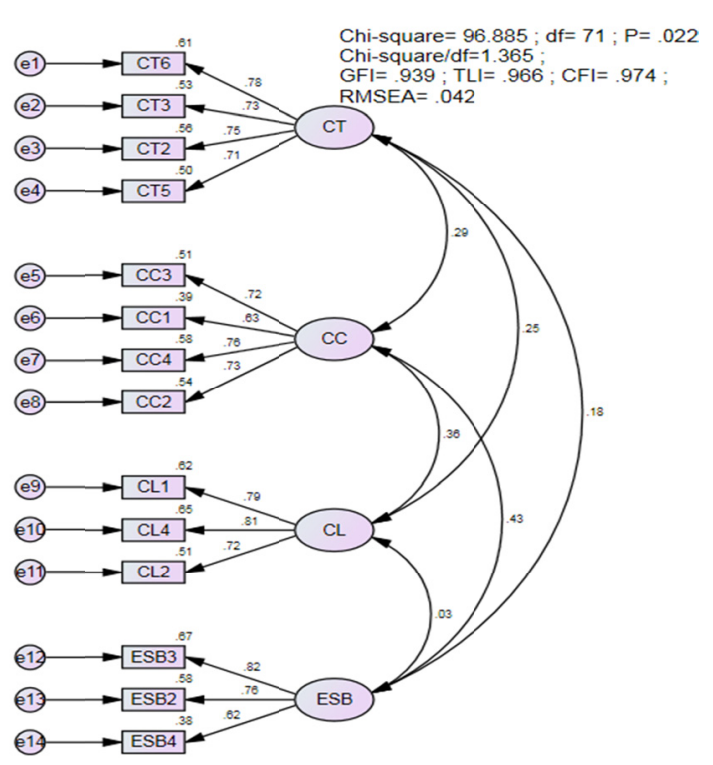

Figure 2. CFA result

\subsection{Testing Structural Model}

In the first attempt, the standardized regression coefficient (-.164) between Ethical Sales Behavior (ESB) and Customer Loyalty (CL) is not significant. Hence, the relationship between ESB and CL is removed.

In the second attempt, the standardized regression coefficient (.165) between Customer Commitment (CC) and Customer Loyalty (CL) is not significant. Hence, the relationship between CC and CL is removed.

In the third attempt, all criteria to assess model fit are met, i.e.

- $\chi 2 / \mathrm{df}=1.365 \leq 2$

- $\mathrm{GFI}=.939>.9$

- $\mathrm{CFI}=.966>.9$

- RMSEA $=.042 \leq .08$

Hence, all relationships between ESB and CT, ESB and CC, CT and CC, CT and CL are supported as shown in the Figure 3. 

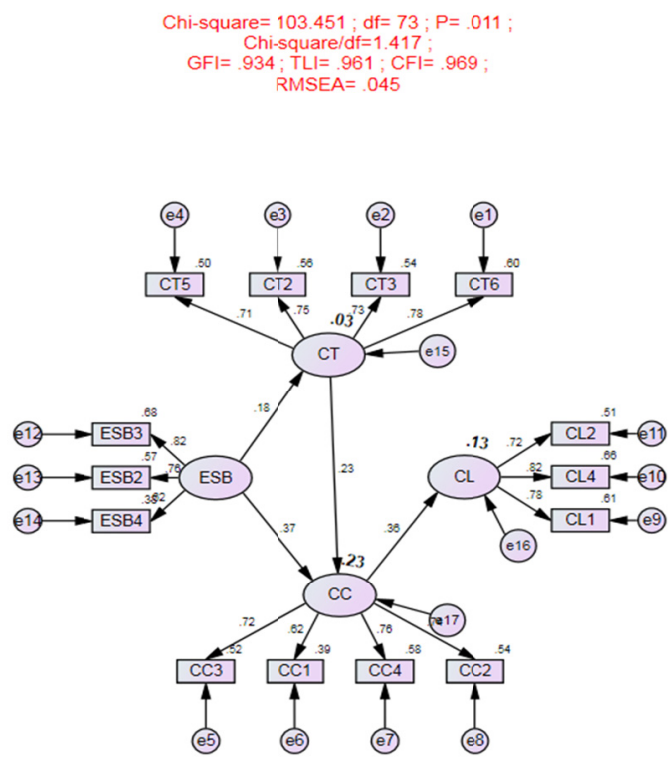

Figure 3. SEM result

i.e. the following statements have been confirmed:

- Ethical sales behavior has positive effect customer trust.

- Ethical sales behavior has positive effect on customer commitment.

- Customer trust has positive effect on customer commitment.

- Customer commitment has positive effect on customer loyalty.

- However, the following hypotheses have not been supported

- Customer trust has positive effect on customer loyalty.

- Ethical sales behavior has positive effect on customer loyalty.

4.5 Multiple group analysis

Multiple group analyses are performed based on

- Gender (male and female).

- Purchasing power (high: 200 million VND or more, low: less than 200 million VND).

Variance or invariance models are selected based on the difference of Chi-square between them.

Based on Figures $4 a, 4 b, 5 a$, and 5b, the p-values for the differences between models are calculated in Excel as follows:

- $\quad$ For Gender: $=$ CHIDIST $((189.225-187.414),(150-146))=.77(>.05)$

- For Purchasing Power: $=$ CHIDIST $((212.938-209.587),(150-146))=.50(>.05)$ 


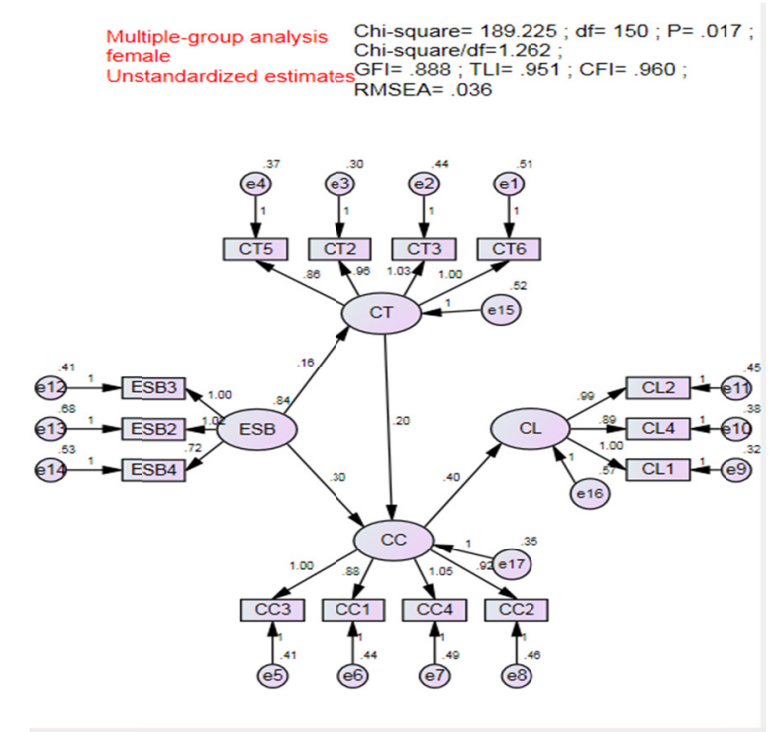

Figure 4a. Invariance model

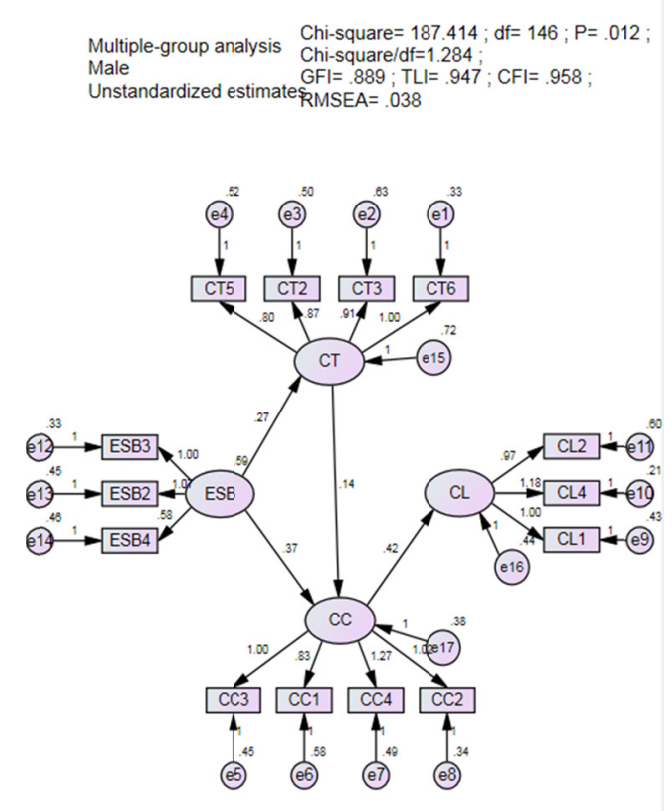

Figure 4b. Variance Model 
Chi-square $=212.938 ; \mathrm{df}=150 ; \mathrm{P}=.001$ Chi-square/df=1.420

CFI $=875 ; \mathrm{TLI}=924 ; \mathrm{CFI}=.938$

Unstandardized estimates RMSEA

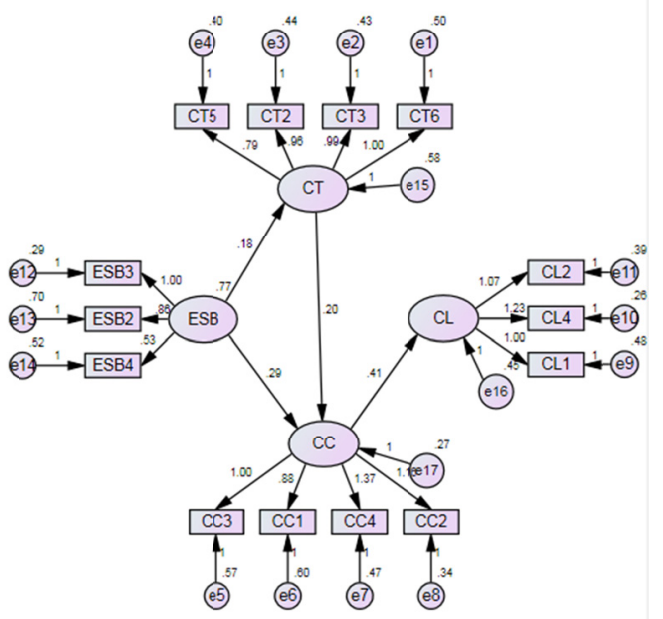

Figure 5a. Invariance model

$$
\begin{array}{ll}
\text { Multiple-group analysis } & \text { Chi-square=209.587; } \mathrm{df}=146 ; \mathrm{P}=.000 \\
\text { highaveragemonthlybill } & \mathrm{GFI}=.877 ; \mathrm{TLI}=.436 ; ; \mathrm{CFI}=.937 ; \\
\text { Unstandardized estimates } & \mathrm{RMSEA}=.047
\end{array}
$$

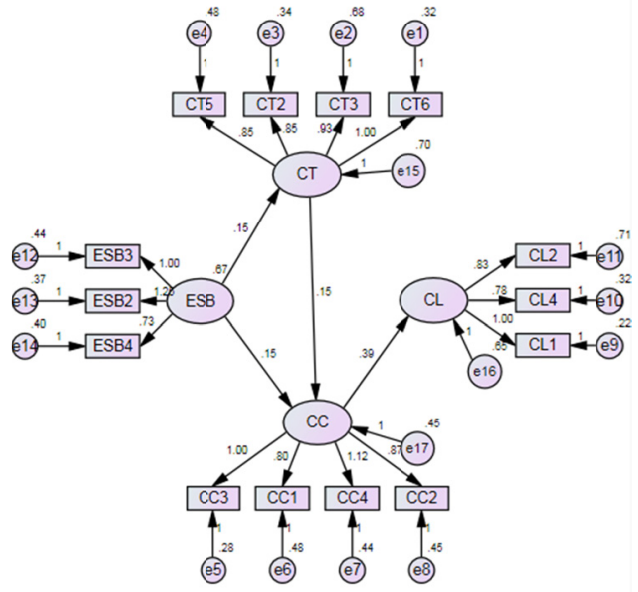

Figure 5b. Variance model

The result suggests invariance models be selected in both cases, and there is no difference in gender or purchasing power regarding the impact of ethical sales behavior on customer loyalty.

\section{Discussion}

Various studies on the impact of ethical sales behavior on customer loyalty through customer trust and customer commitment have been carried out in banking or life insurance sector; however, no such a study has been conducted in FMCG industry in Vietnam. Therefore, the findings and recommendation of this current research not only can be used as solutions for $P \& G$ but also for fast-moving-consumer-good (FMCG) industry regarding ethical sales behavior of salespersons.

Customer loyalty which can affect risk and profits is very important to any business. Therefore, customer loyalty is an ever-present keyword in any company's board meetings and marketing strategy (Pauwels \& Reibstein, 2010). In addition, loyal customers serve as unpaid advocates to increase the brand reputation of company, and 
they are willing to pay higher for products they trust. Salespersons who act as a bridge between businesses and customers can create positive impression on customers through honest actions. This current study shows that ethics from salespersons does not have direct impact on customer loyalty, but can indirectly stimulate customer loyalty through the establishment of customer trust and commitment in relationship quality. This is consistent with results of other studies (e.g. Leonidou, Kvasova, Leonidou, \& Chari, 2013; M'Sallem, Bouhlel, \& Mzoughi, 2011; Chen \& Mau, 2009). Therefore, the management strategies may be more fruitful with aiming to the internal process to enhance the degree of trust and commitment from customers, which give rise to loyalty in future. By this way, businesses should have appropriate policies to recruit the salespersons as well as strengthen the ethics in sales for their representatives to encourage customer's confidence. Various exploratory studies proved that company's ethical workplace significantly impacts on the ethics of its employees (Huang, You, \& Tsai, 2013; Shin, 2012; Verbeke, Ouwerkerk, \& Peelen, 1996; Wimbush \& Shepard, 1994). Accordingly, company should set ethical rules or guidelines for salespersons and design the appropriate training programs or reward mechanisms. Likewise, Schwartz (2013), Roman and Munuera (2005), Verbeke et al. (1996) argued that in order to create an organization trustworthy culture, businesses should begin to shape confidence in internal processes first by creating, implementing, educating, training, and monitoring new codes of ethics for employees. Moreover, businesses should build up a good communication channel with customers to receive earlier feedbacks about salespersons' unethical behaviors. In other words, customers can play the role of supervisors in following and preventing salespersons from behaving unethically, but without payments. Furthermore, our face-to-face interviews showed that many customers were not aware of promotional programs. This gave way to unethical sales behaviors. So, businesses in general, and $P \& G$ in particular should implement promotional campaigns where information flows transparently. Finally, the direct impact of customer trust on customer loyalty is not discovered in this current study, but indirect effect through customer commitment as a mediating variable is found. However, this contradicts to other studies (e.g. Pezhman, Javadi, \& Shahin, 2013; Lin, 2012; Chen \& Mau, 2009; Yen \& Gwinner, 2003; Reynolds \& Beatty, 1999), where customer trust directly influence customer loyalty.

This current study also indicates that there be not any moderating effect of gender or purchasing power on the relationship between ethical sales and customer loyalty. This result is quite new regarding the understanding of the author.

\section{Limitations and Further Research}

This current study explored the customer's perceptions toward ethical sales behaviors, which have seldom been concerned by other researchers yet. The customer loyalty model used by Alrubaiee (2012) was confirmed again in a different context. Nevertheless, further researches should be conducted in other business sectors to ensure its comprehensive applicability. Moreover, different complaint themes can influence customer commitment then customer loyalty with different tension (Bunker, 2008). Therefore, $P \& G$ should not just focus on the most frequent complaint issue, but further researches for $P \& G$ should be conducted on the impact levels of complaint groups to prioritize areas for improvement.

\section{Acknowledgments}

The author would like to thank Dinh Thi Xuan Huong for data collection and Nguyen Thi Cat Ngoc for the paper arrangement.

\section{References}

Adamson, I., Chan, K., \& Handford, D. (2003). Relationship marketing: Customer commitment and trust as a strategy for the smaller Hong Kong corporate banking sector. International Journal of Bank Marketing, 21(6/7), 347-358. http://dx.doi.org/10.1108/02652320310498492

Agnihotri, R., Kothandaraman, P., \& Kashyap, R. (2012). Bringing "Social" into Sales: The Impact of Salespeople 's Social Media Use on Service Behaviors and Value Creation. Journal of Personal Selling and Sales Management, 32, 333-348. http://dx.doi.org/10.2753/PSS0885-3134320304

Alrubaiee, L. (2012). Exploring the relationship between ethical sales behavior, relationship quality and customer loyalty. International Journal of Marketing Studies, 4(1), 7-25. http://dx.doi.org/10.5539/ijms.v4n1p7

Alrubaiee, L., \& Al-Nazer, N. (2010). Investigate the impact of relationship marketing orientation on customer loyalty: The customer's perspective. International Journal of Marketing Studies, 2(1), 155-174. http://dx.doi.org/10.5539/ijms.v2n1p155

Anderson, J. C., \& Gerbing, D. W. (1988). Structural equation modeling in practice: A review and recommended 
two-step approach. Psychological Bulletin, 103(3), 411-423. http://dx.doi.org/10.1037/0033-2909.103.3.411

Anderson, J. C., \& Narus, J. A. (1990). A model of distributor firm and manufacturer firm working partnerships. Journal of Marketing, 54(January), 42-58. http://dx.doi.org/10.2307/1252172

Beatty, S. E., Mayer, M., Coleman, J. E., Reynolds, K. E., \& Lee. (1996). Customer-Sales Associate Retail Relationships. Journal of Retailing, 72(3), 223-247. http://dx.doi.org/10.1016/S0022-4359(96)90028-7

Bettencourt, L. A. (1997). Customer voluntary performance: Customers as partners in service delivery. Journal of Retailing, 73(3), 383-406. http://dx.doi.org/10.1016/S0022-4359(97)90024-5

Bloemer, J. M. M., \& De Ruyter, K. (1999). Customer loyalty in high and low involvement settings: The moderating impact of positive emotions. Journal of Marketing Management, 15(4), 315-330. http://dx.doi.org/10.1362/026725799784870388

Bunker, M. P. (2008). The importance of understanding different complaint themes' impact on commitment. International Journal of Consumer Studies, 32(6), 628-632. http://dx.doi.org/10.1111/j.1470-6431.2008.00717.x

Burnett, M., Pettijohn, C., \& Keith, N. (2008). A comparison of the ethical perceptions prospective personal selling and advertising employees. The Marketing Management Journal, 18(1), 77-83.

Cater, B., \& Zabkar, V. (2008). Antecedents and consequences of commitment in marketing research services: The client's perspective. Industrial Marketing Management, 38(7), 785-797. http://dx.doi.org/10.1016/j.indmarman.2007.10.004

Chang, Y. H., \& Chen, F. Y. (2007). Relational benefits, switching barriers and loyalty: A study of airline customers in Taiwan. Journal of Air Transport Management, 13, 104-109. http://dx.doi.org/10.1016/j.jairtraman.2006.10.001

Chen, P. T., \& Hu, H. H. (2010). The effect of relational benefits on perceived value in relation to customer loyalty: An empirical study in the Australian coffee outlets industry. International Journal of Hospitality Management, 29(3), 405-412. http://dx.doi.org/10.1016/j.ijhm.2009.09.006

Chen, M. F., \& Mau, L. H. (2009). The impact of ethical sales behavior on customer loyalty in the life insurance industry. The Service Industry Journal, 29(1), 59-74. http://dx.doi.org/10.1080/02642060802116339

Churchill, G. A. Jr. (1995). Marketing Research Methodological Foundations (6th ed.). Fort Worth, TX: Dryden Press.

Cooper, R. W., \& Frank, G. L. (2002). Ethical challenges in the two main segments of the insurance industry: Key considerations in the evolving financial services marketplace. Journal of Business Ethics, 36(1/2), 5-20. http://dx.doi.org/10.1023/A:1014235908833

Cortina, J. M. (1993). What is coefficient alpha? An examination of theory and applications. Journal of Applied Psychology, 78, 98-104. http://dx.doi.org/10.1037/0021-9010.78.1.98

Costello, A. B., \& Osborne, J. W. (2005). Best practices in exploratory factor analysis: Four recommendations for getting the most from your analysis. Practical Assessment, Research and Evaluation, 10(7), 1-9.

Coulter, K. S., \& Coulter, R. A. (2003). The effects of industry knowledge on trust in service relationships. International Journal of Research in Marketing, 20(March), 31-43. http://dx.doi.org/10.1016/S0167-8116(02)00120-9

Cristobal, E., Flavian, C., \& Guinaliu, M. (2007). Perceived e-service quality (PeSQ): Measurement validation and effects on consumer satisfaction and web site loyalty. Managing Service Quality, 17(3), 317-340. http://dx.doi.org/10.1108/09604520710744326

Crosby, L. A., Evans, K. R., \& Cowles, D. (1990). Relationship quality in services selling: An interpersonal influence perspective. Journal of Marketing, 54(3), 68-81. http://dx.doi.org/10.2307/1251817

De Wulf, K., Oderkerken-Schroder, G., \& Iacobucci, D. (2001). Investment in consumer relationships: Across-country and cross-industry exploration. Journal of Marketing, 65, 33-50. http://dx.doi.org/10.1509/jmkg.65.4.33.18386

Dimitriades, Z. S. (2006). Customer satisfaction, loyalty and commitment in service organizations: Some evidence from Greece. Management Research News, 29(12), 782-800. http://dx.doi.org/10.1108/01409170610717817

Dunfee, T. W., \& Gunther, R. (1999). Ethical issues in financial services. Business and Society Review, 104(1), 


\section{5-12. http://dx.doi.org/10.1111/0045-3609.00032}

Dwyer, F. R., Schurr, P. H., \& Oh, S. (1987). Developing buyer-seller relationships. Journal of Marketing, 51(2), 11-27. http://dx.doi.org/10.2307/1251126

Ferrell, O. C., \& Gresham, L. G. (1985). A contingency framework for understanding ethical decision making in marketing. Journal of Marketing, 49(3), 84-96. http://dx.doi.org/10.2307/1251618

Fullerton, G. (2003). When does commitment lead to loyalty? Journal of Service Research, 5(4), 333-344. http://dx.doi.org/10.1177/1094670503005004005

Futrell, C. M. (2002). Fundamentals of selling: Customers for life (7th ed.). New York: McGraw Hill.

Ganesan, S. (1994). Determinants of long-term orientation in buyer- seller relationships. Journal of Marketing, 58, 1-19. http://dx.doi.org/10.2307/1252265

Ganesh, J., Arnold, M. J., \& Reynolds, K. E. (2000). Understanding the customer base of service providers: An examination of the differences between switchers and stayers. Journal of Marketing, 64(3), 65-87. http://dx.doi.org/10.1509/jmkg.64.3.65.18028

Gerpott, T. J., Rams, W., \& Schindler, A. (2001). Customer retention, loyalty and satisfaction in the German mobile cellular telecommunications market. Telecommunications Policy, 25(4), 249-269. http://dx.doi.org/10.1016/S0308-5961(00)00097-5

Gilliland, D. I., \& Bello, D. C. (2002). Two sides to attitudinal commitment: The effect of calculative and loyalty commitment on enforcement mechanisms in distribution channels. Journal of the Academy of Marketing Science, 30(1), 24-43. http://dx.doi.org/10.1177/03079450094306

Gregoire, Y., \& Fisher, R. J. (2006). The effects of relationship quality on customer retaliation. Market Lett, 17, 31-46. http://dx.doi.org/10.1007/s11002-006-3796-4

Grönroos, C. (1990). Service Management and Marketing. Massachusetts, USA: Lexington Books.

Gruen, T. W., Summers, J. O., \& Acito, F. (2000). Relationship marketing activities, commitment, an membership behaviors in professional associations. Journal of Marketing, 64(3), 34-49. http://dx.doi.org/10.1509/jmkg.64.3.34.18030

Hansen, J. D., \& Riggle, R. J. (2009). Ethical salesperson behavior in sales relationships. Journal of Personal Selling and Sales Management, 29(2), 151-166. http://dx.doi.org/10.2753/PSS0885-3134290204

Hazrati, S. S., Zohdi, M., Zohdi, M. H., Seyedi, S. M., \& Dalvand, M. T. (2012). Examining impacts of the salesperson's ethical behavior on the customer's satisfaction, trust and commitment. African Journal of Business Management, 6(14), 5026-5033.

Hess, J., \& Story, J. (2005). Trust-based commitment: multidimensional consumer-brand relationships. Journal of Consumer Marketing, 22(6), 313-322. http://dx.doi.org/10.1108/07363760510623902

Holland, P. W., \& Wainer, H. (1993). Differential Item Functioning. Hillsdale, NJ: Erlbaum.

Howe, V., Hoffman, K. D., \& Hardigree, D. W. (1994). The relationship between ethical and customer-oriented service provider behaviors. Journal of Business Ethics, 13(July), 497-506. http://dx.doi.org/10.1007/BF00881295

Hu, L. T., \& Bentler, P. M. (1995). Evaluating model fit. In R. H. Hoyle (Ed.), Structural Equation Modeling: Concepts, issues and applications (pp. 76-99). Thousand Oaks, CA: Sage.

Huang, C., You, C., \& Tsai, M. (2012). A multidimensional analysis of ethical climate, job satisfaction, organizational commitment, and organizational citizenship behaviors. Nursing Ethics, 19(4), 513-529. http://dx.doi.org/ 10.1177/0969733011433923

Jacoby, J., \& Chestnut, R. (1978). Brand Loyalty: Measurement and Management. New York: John Wiley and Sons.

Jöreskog, K. G. (1999). Some contributions to maximum likelihood factor analysis. Psychometrika, 32, 443-482. http://dx.doi.org/10.1007/BF02289658

Josep, M. R., \& Velilla, M. (2003). Loyalty and trust as the ethical bases of organizations. Journal of Business Ethics, 44(1), 49-59. http://dx.doi.org/10.1023/A:1023238525433

Karande, K., Jungbok, H., \& Anusorn, S. (2008). The role of contextual factors in relationship commitment of buyers to foreign suppliers: A survey of Korean importers. Industrial Marketing Management, 37(7), 
856-862. http://dx.doi.org/10.1016/j.indmarman.2008.01.010

Kelly, K., \& Schine, E. (1992, June 29). How did Sears blow this gasket? Business Week, p. 38.

Kennedy, M. S., Ferrell, L. K., \& Leclair, D. T. (2001). Consumers' trust of salesperson and manufacturer: An $\begin{array}{lllll}\text { empirical study. Journal of Business Research, } & \text { 51(1), }\end{array}$ http://dx.doi.org/10.1016/S0148-2963(99)00039-9

Lagace, R. R., Dahlstrom, R., \& Gassenheimer, J. B. (1991). The relevance of ethical salesperson behavior on relationship quality: The pharmaceutical industry. Journal of Personal Selling and Sales Management, 11(4), $39-47$.

Leonidou, L. C., Kvasova, O., Leonidou, C. N., \& Chari, S. (2013). Business Unethicality as an Impediment to Consumer Trust: The Moderating Role of Demographic and Cultural Characteristics. Journal of Business Ethics, 112(3), 397-415. http://dx.doi.org/10.1007/s10551-012-1267-9

Lin, S. H. (2012). Effects of ethical sales behavior considered through transaction cost theory: To whom is the customer loyal. The Journal of International Management Studies, 7(1), 31-40.

McDonald, R. P. (1985). Factor Analysis and Related Methods. Hillsdale: Erlbaum.

Mishra, K. E., \& Li, C. (2008). Relationship Marketing in Fortune 500 U.S. and Chinese Web Sites. Journal of Relationship Marketing, 7(1), 29-43. http://dx.doi.org/10.1080/15332660802067882

Moorman, C., Zaltman, G., \& Deshpande, R. (1992). Relationships between providers and users of market research: the dynamics of trust within and between organizations. Journal of Marketing Research, 29(3), 314-328. http://dx.doi.org/10.2307/3172742

Morgan, R. M., \& Hunt, S. D. (1994). The commitment - trust theory of relationship marketing. Journal of Marketing, 58(3), 20-38. http://dx.doi.org/10.2307/1252308

M'Sallem, W., Bouhlel, O., \& Mzoughi, M. N. (2011). The Perceived Ethical Behavior of Bankers: A North African Perspective. Australian Journal of Business and Management Research, 1(2), 45-54.

Oliver, R. L. (1999). Whence customer loyalty? Journal of Marketing, 63, 33-44.

Palmatier, R. W., Dant, R. P., Grewal, D., \& Evans, K. R. (2006). Factors influencing the effectiveness of relationship marketing: A meta-analysis. Journal of Marketing, 70(October), 136-153. http://dx.doi.org/10.1509/jmkg.70.4.136

Pauwels, K., \& Reibstein, D. (2010). Challenges in measuring return on marketing investment: Combining research and practice perspectives. Review of Marketing Research, 6, 107-124. http://dx.doi.org/10.1108/S1548-6435(2009)0000006009

Pezhman, R., Javadi, M. H. M., \& Shahin, A. (2013). Analyzing the Influence of Ethical Sales Behavior on Customers Loyalty through Customer Satisfaction and Trust in Insurance Company. International Journal of Academic Research in Business and Social Sciences, 3(9), 754-763.

Poujol, J. F., Siadou-Martin, B., Vidal, D., \& Pellat, G. (2012). Examining the impact of salespeople's relational behaviors and organizational fairness on customer loyalty. Paper presented at the $12^{\text {th }}$ International Research Conference in Service Management, La Londe les Maures, France.

Ramsey, R., Marshall, G. W., Johnston, M., \& Deeter-Schmelz, D. R. (2007). Ethical ideologies and older consumer perceptions of unethical sales tactics. Journal of Business Ethics, 70(2), 191-207. http://dx.doi.org/10.1007/s10551-006-9105-6

Robertson, D. C., \& Anderson, E. (1993). Control system and task environment effects of ethical judgment: An exploratory study of industrial sales people. Organization Science, 4(4), 617-644. http://dx.doi.org/10.1287/orsc.4.4.617

Roman, S. (2003). The impact of ethical sales behaviour on customer satisfaction, trust and loyalty tothe company: An empirical study in the financial services industry. Journal of Marketing Management, 19(9/10), 915-939. http://dx.doi.org/10.1080/0267257X.2003.9728245

Roman, S., Munuera, J. L. (2005). Determinants and consequences of ethical behavior: An empirical study of salespeople. European Journal of Marketing, 39(5-6), 473-495. http://dx.doi.org/10.1108/03090560510590674

Roman, S., \& Ruiz, S. (2005). Relationship outcomes of perceived ethical sales behaviour: The customer's perspective. Journal of Business Research, 58(4), 439-445. http://dx.doi.org/10.1016/j.jbusres.2003.07.002 
Rust, R. T., Zeithaml, V. A., \& Lemon, K. N. (2000). Driving customer equity: How customer lifetime value is reshaping corporate strategy. New York: Free Press.

Reynolds, K. E., \& Beatty, S. E. (1999). Customer Benefits and Company Consequences of Customer-Salesperson Relationships in Retailing. Journal of Retailing, 75(1), 11-32. http://dx.doi.org/10.1016/S0022-4359(99)80002-5

Sanzo, M. J., Santos, M. L.,Vazquez, R., \& Alvarez, L. (2003). The role market orientation in business dynamic relationships: Testing an integrator model. Journal of Marketing Management, 19(1/2), 73-107. http://dx.doi.org/10.1080/0267257X.2003.9728202

Schiffmann, L. G., \& Kanuk, L. L. (2000). Consumer Behavior (7th ed.). New Jersey: Prentice Hall.

Schwartz, M. S. (2013). Developing and sustaining an ethical corporate culture: The core elements. Business Horizons, 56(1), 39-50. http://dx.doi.org/ 10.1016/j.bushor.2012.09.002

Selnes, F., \& Gonhaug, K. (2000). Effects of supplier reliability and benevolence in business marketing. Journal of Business Research, 49(3), 259-270. http://dx.doi.org/10.1016/S0148-2963(99)00017-X

Shin, Y. (2012). CEO Ethical Leadership, Ethical Climate, Climate Strength, and Collective Organizational Citizenship Behavior. Journal of Business Ethics, 108(3), 299-312. http://dx.doi.org/10.1007/s10551-011-1091-7

Sirdeshmukh, D., Singh, J., \& Sabol, B. (2002). Consumer trust, value, and loyalty in relational exchanges. Journal of Marketing, 66(1), 15-37. http://dx.doi.org/10.1509/jmkg.66.1.15.18449

Speckman, R. E. (1988). Strategic supplier selection: Understanding long-term buyer relations. Business Horizons, 31, 75-81. http://dx.doi.org/10.1016/0007-6813(88)90072-9

Stanko, M., Bonner, J., \& Calantone, R. (2007). Building commitment in buyer-seller relationships: A tie strength perspective. Industrial Marketing Management, 36, 1094-1103. http://dx.doi.org/10.1016/j.indmarman.2006.10.001

Swan, J. E., Bowers, M. R., \& Richardson, L. D. (1999). Customer trust in the salesperson: An integrative review and meta-analysis of the empirical literature. Journal of Business Research, 44(2), 93-107. http://dx.doi.org/10.1016/S0148-2963(97)00244-0

Ulaga, W., \& Reinartz, W. (2011). Hybrid offerings: How manufacturing firms combine goods and services successfully. Journal of Marketing, 75(6), 5-23. http://dx.doi.org/10.1509/jm.09.0395

Valentine, S., \& Barnett, T. (2007). Perceived organizational ethics and the ethical decisions of sales and marketing personnel. Journal of Personal Selling and Sales Management, 27(4), 373-388. http://dx.doi.org/10.2753/PSS0885-3134270407

Veloutsou, C., Saren, M., \& Tzokas, N. (2002). Relationship marketing what if.... European Journal of Marketing, 36(4), 21-28. http://dx.doi.org/10.1108/03090560210417255

Verbeke, W., Ouwerkerk, C., \& Peelen, E. (1996). Exploring the contextual and individual factors on ethical decision making of salespeople. Journal of Business Ethics, 15(11), 1175-87. http://dx.doi.org/10.1007/BF00412816

Vuuren, T. V., Roberts-Lombard, M., \& Tonder E. V. (2012). Customer satisfaction, trust and commitment as predictors of customer loyalty within an optometric practice environment. Southern African Business Review, 16(3), 81-96.

Weeks, W. A., Loe, T. W., Chonko, L. B., \& Wakefield, K. (2004). The effect of perceived ethical climate on the search for sales force excellence. Journal of Personal Selling and Sales Management, 24(3), 199-214.

Widaman, K. F., \& Reise, S. P. (1997). Exploring the measurement invariance of psychological instruments: Applications in the substance use domain. In K. J. Bryant, M. Windle, \& S. G. West (Eds.), The science of prevention: Methodological advances from alcohol and substance abuse research (pp. 281-324). Washington, DC: American Psychological Association.

Wimbush, J. C., \& Shepard, J. M. (1994). Toward an understanding of ethical climate: Its relationship to ethical behavior and supervisory influence. Journal of Business Ethics, 13(8), 637-647. http://dx.doi.org/10.1007/BF00871811

Yen, H. J., \& Gwinner, K. P. (2003). Internet Retail Customer Loyalty: The Mediating Role of Relational Benefits. International Journal of Service Industry Management, 14(5), 483-500. 
http://dx.doi.org/10.1108/09564230310500183

\section{Appendix A}

\section{Questionnaire}

The Impact of Ethical Sales Behavior on Customer Loyalty: The Case of Procter \& Gamble Vietnam Co. Ltd Dear Mr/Mrs

On the behalf of P\&G Company in Vietnam, I would appreciate hearing your opinion about ethical sales behaviors to improve the quality of sale person and serve customers better. Please take a couple of minutes to complete a questionnaire survey below. Any of information you provide will be kept strictly confidential and will not be attributed to the individual or organization. Your help would be greatly appreciated.

Thank you very much for your time and cooperation.

\section{General Information}

1. What is your gender?

a. Male

b. Female

2. Where is your hometown?

a. Northern Region

b. Central Region

c. Southern Region

d. Western Region

3. Do you buy $P \& G$ products at Metro supermarket system monthly?

a. Yes

b. No

4. How much is the average monthly bill?

a. Less than 100 million VND

b. $\quad 100-200$ million VND

c. 200-300 million VND

d. More than 300 million VND

Please Check (X) for the Most Suitable Options of the Scales

1. Strongly disagree

2. Disagree

3. Neutral

4. Agree

5. Strongly agree

\begin{tabular}{|c|c|c|c|c|c|c|}
\hline \multicolumn{7}{|c|}{ Ethical Sales Behavior } \\
\hline NO. & QUESTION & 1 & 2 & 3 & 4 & 5 \\
\hline 1 & Salespersons lie about availability of promotion programs. & & & & & \\
\hline 2 & $\begin{array}{l}\text { When promotional goods are out of stock at Metro, salespersons confirm in writing about the delivery } \\
\text { appointment on the bill. }\end{array}$ & & & & & \\
\hline 3 & $\begin{array}{l}\text { When promotional goods are out of stock at Metro, salespersons confirm in writing about the quantity on } \\
\text { the bill. }\end{array}$ & & & & & \\
\hline 4 & Salespersons give sufficient amounts of promotional goods. & & & & & \\
\hline 5 & $\begin{array}{l}\text { Salespersons deliver promotional goods in the period of delivery appointment or after } 2 \text { weeks of } \\
\text { purchasing. }\end{array}$ & & & & & \\
\hline
\end{tabular}




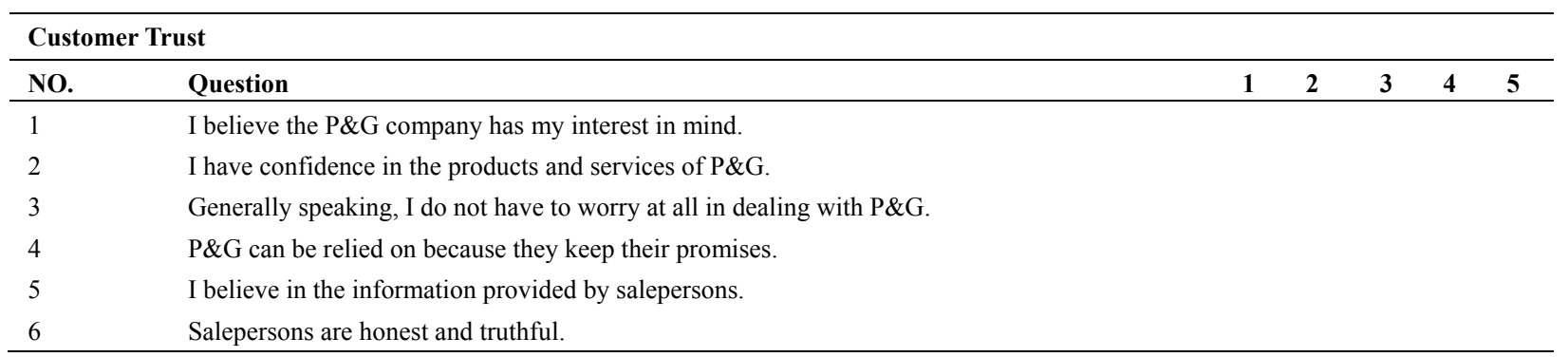

\begin{tabular}{|c|c|c|c|c|c|c|}
\hline \multicolumn{7}{|c|}{ Customer Committee } \\
\hline No. & Question & 1 & 2 & 3 & 4 & 5 \\
\hline 1 & I want to remain a customer of $P \& G$ because I genuinely enjoy my relationship with P\&G. & & & & & \\
\hline 2 & My relationship with $P \& G$ is one that I really care about. & & & & & \\
\hline 3 & I am very committed to the relationship with $P \& G$. & & & & & \\
\hline 4 & My relationship with $P \& G$ is very important to me. & & & & & \\
\hline 5 & My relationship with $P \& G$ is something I intend to maintain indefinitely. & & & & & \\
\hline
\end{tabular}

\begin{tabular}{|c|c|c|c|c|c|c|}
\hline \multicolumn{7}{|c|}{ Customer Loyalty } \\
\hline NO. & Questions & 1 & 2 & 3 & 4 & 5 \\
\hline 1 & I am willing to place my future business with $P \& G$. & & & & & \\
\hline 2 & I will recommend this company to my friends and relatives. & & & & & \\
\hline 3 & I will introduce this company with positive evaluation. & & & & & \\
\hline 4 & I am willing to encourage others to do business with this company. & & & & & \\
\hline
\end{tabular}

\section{Appendix B}

\section{Interview Questions}

1. How could you recognize when salespersons were lying to you about $P \& G$ products at Metro Cash \& Carry?

2. When did salespersons not give sufficient gift vouchers or promotional products?

3. How many gift vouchers or promotional products have they not transferred to you yet?

4. When you knew the untrustworthy salesperson no longer worked at Metro Cash and Carry, what did you do?

5. After such incident, do you still trust $P \& G$ company?

6. After such incident, do you still keep commitment with $P \& G$ ?

7. After such incident, do you intend to switch to other brands?

\section{Copyrights}

Copyright for this article is retained by the author(s), with first publication rights granted to the journal.

This is an open-access article distributed under the terms and conditions of the Creative Commons Attribution license (http://creativecommons.org/licenses/by/3.0/). 